\title{
The Effect of Capital Structure, Company Growth, and Profitability on Firm Value
}

\author{
Victorius Marlon Lanjas $^{1 *} \quad$ Sutriswanto $^{2} \quad$ Nanik Sisharini $^{2}$ \\ 1.Student in Program of Magister Management, University of Merdeka Malang, Indonesia \\ 2.Faculty of Economic and Business, University of Merdeka Malang, Indonesia
}

\begin{abstract}
This study aims to determine the effect of capital structure, company growth, and profitability on a firm's value. The independents variable in this study is capital structure, company growth, and profitability. The dependent variable in this study is the firm's value. The type of this research is an empirical study and used the secondary data which were obtained by the documentation technique. This study observed coal mining companies listed on Indonesia Stock Exchange from 2015 to 2019. The sample was obtained by the purposive sampling method. The analysis data used in this study was multiple linear regression analysis. The result of this analysis states that capital structure, company growth, and profitability affect a firm's value simultaneously. The most dominant variable is profitability, while company growth and capital structure are not the dominant variables on firm value.
\end{abstract}

Keywords: Capital structure, Company growth, Profitability, Firm's value.

DOI: $10.7176 /$ RJFA/12-6-09

Publication date:March $31^{\text {st }} 2021$

\section{Introduction}

With increased economic growth, the need for a country's energy resources will increase. One sector, namely mining, is one of the pillars of a country's economic development, due to its strategic role as a provider of energy resources needed for economic growth in a country. Indonesia is one of the countries that have abundant natural resources, including the mining sector. The rise of industry in a globalized manner has an important meaning in the era of globalization and has an impact on international trade, therefore countries in the world are trying to meet domestic energy supplies so that their industries can run (Salvatore, 2011).

The main goal of the company in the short term is to maximize profits, while the long term goal of the company is to maximize the value of the company (Salvatore, 2011). The value of a company that goes public can be seen through the supply and demand mechanism on the stock exchange, which is reflected in the company's stock price. The stock market price is an indicator of how the market values the company as a whole. Stocks are one of the most popular instruments chosen by investors because they provide attractive returns. One aspect that is used as an assessment material for investors is the corporate value market.

The higher the company value, the more prosperous the shareholders will be. According to (Prasetyo, 2011:158) a high company value is the hope of shareholders (owners) because high company value indicates a high level of shareholder wealth. Firm value for investors is an important concept because it is an indicator of how the market values the company as a whole. High corporate value is the desire of company owners because a high value indicates high shareholder prosperity. High company value indicates good company performance.

Capital structure is the proportion of funding to debt (debt financing) of the company, namely the company's leverage ratio, wherein measuring the company's leverage can use the debt equity ratio (DER). If the position of the capital structure is above the optimal capital structure target, then any increase in debt will decrease the firm's value, this is based on capital structure theory. Suzulia et al. (2020) research shows that capital structure has a positive and significant effect on firm value. The composition of the capital structure that is right and used optimally can provide positive value for company value. The positive direction here means that the more precise and optimal the composition of the company's capital structure, the greater the company's value that can be achieved. Hardinis (2019) shows that capital structure has a positive and significant effect on firm value. Additional debt activities undertaken by a company to expand its business will increase the share price of the company so that the company's value increases significantly.

Company growth is one of the factors related to company value. The growth of a company is how far the company places itself in the overall economic system for the same industry. In measuring the growth of a company, it can be seen the growth in total assets (Asset Growth) it has. Asset Growth measures the amount of increase in total assets from year to year. Investors responded positively to information about the company's growth, thus increasing share prices. Research by Fajaria and Isnalita (2018) states that company growth has a significant positive effect on company values. In Suzulia et al. (2020) company growth does not have a significant effect on firm value. The results of this study are in line with research by Meythi and Debbianita (2012). Management of a growing company requires large funds for its operations. Company funds are more focused on supporting the company's growth than on the welfare of its shareholders. This is because investors have more confidence in established companies than in developing companies. Therefore, although the company's growth is high, it does 
not have a significant effect on firm value.

Husnan and Pudjiastuti (2015:76) state that profitability intended to measure how much the company generates profit from sales, and the assets it owns or from the equity it owns. Profitability is considered as one of the information released by the company that can be used as a signal for investors to attract investors and want to invest in the company. When the market reaction responds positively to the signal issued by the company, it will increase the value of the company. In Suzulia et al. (2020) research shows that profitability has a positive effect on firm value. This means that the increase in company profitability is in line with the increase in firm value. Research by Fajaria and Isnalita (2018) also shows that profitability has a positive effect on firm value. Return on equity which is stated is the rate of return or part of the profit to the shareholders. Thus, a high return on equity indicates that the company can provide a high return of shareholders. This will attract investors to buy company shares and result in an increase in share prices. Research by Aggarwal and Padhan (2017) shows that profitability measured using a return on assets (ROA) has a negative effect on company values.

Based on the above discussion, previous theories and studies on the influence of capital structure, firm growth, and profitability on corporate value show inconsistent results. This study was conducted to determine the effect of capital structure, firm growth, and profitability on corporate value.

\section{Review Of Literature And Hypothesis Development}

The concept of agency theory according to R. A Supriyono (2018:63) is a contractual relationship between the owner (principal) and management (agent), the owner contracts management to work for a specific purpose so that management is given the authority to make decisions. Agency theory has a relationship with income smoothing, explaining that agents and principals often have different interests. The agency relationship is defined as a contract in which one or more people (called owners or shareholders or owners) appoint another person (called an agent or administrator or management) to do some work on behalf of the owner. This work includes the delegation of authority to make decisions. In this case, management is expected by the owner to be able to optimize the existing resources optimally. If both parties are maximizing their roles (utility maximizers), what reason is there that management will not always act in the best interests of the owners. This is very reasonable because in general, the owners have long-term welfare motives, on the other hand, management is more short-term so that sometimes they tend to maximize profits for the short term by ignoring the sustainability of profits in the long term. To limit or reduce this possibility, the owner can set appropriate incentives for management, namely by spending monitoring costs in the form of salaries (Andri Veno, 2015).

Signals are actions taken by the management of a company to guide investors on how management assesses the company's prospects. (Brigham \& Houston, 2019:33). Professors Franco Modigliani and Merton Miller (1958) with their research "The Cost of Capital, Corporation Finance, and The Theory of Investments" in Brigham and Houston (2019:32) assume that every investor and manager has the same information about the prospects of a company. This is known as symmetric information. One type of information released by a company that can be a signal for parties outside the company, especially for investors, is an annual report. Information disclosed in annual reports can be in the form of accounting information, namely information related to financial reports and nonaccounting information, namely information that is not related to financial statements. The annual report should contain relevant information and disclose information deemed important to be known by report users, both inside and outside. All investors need the information to evaluate the relative risk of each company so that they can diversify their portfolio and investment combinations with the desired risk preferences. Signaling theory can also help the company (agent), the owner (principal), and outsiders reduce information asymmetry by producing the quality or integrity of financial statement information (Wijaya, 2012).

The company value is the price that potential buyers are willing to pay if the company is sold (Husnan and Pudjiastuti 2015:6). According to Fahmi (2014:139), company value is a condition that has been achieved by a company as an illustration of public trust in the company after going through a process of activity for several years, namely from the time the company was founded until now. Increasing company value is the achievement of a company in accordance with the wishes of the company owner. This task is specifically delegated to company management to achieve its goals. The higher the value of the company, the more prosperous the company owner is (Kusumajaya, 2011).

The firm value in this study is measured by Tobin's Q. This ratio was developed by Professor James Tobin (1967). The calculation of Tobin's Q in this study follows the calculation method proposed by Kee H. Chung and Stephen W. Pruitt. This ratio is a valuable concept because it shows current financial market estimates of the return on each dollar of investment. Tobin's Q is measured by adding up the market value of shares and the market value of debt compared to the value of share capital placed in assets.

According to Brigham and Houston (2019:4) capital is a fund provided by investors such as long-term and short-term loans from individuals and institutions, preferred stock, common stock, and retained earnings, so the company's capital structure is a mixture of debt, preferred stock, and shares. Used to fund company assets. The capital structure of a company is only part of its financial structure. Meanwhile, the capital structure is the mix 
(proportion) of the company's long-term permanent funding as indicated by debt, preferred stock equity, and common stock (Kusumajaya, 2011).

The debt equity ratio (DER) describes the extent to which owners of capital cover their debts to outsiders (Kasmir, 2019:159). The smaller this ratio, the better. This ratio is also called the leverage ratio. For the outsiders' best security if the total equity ratio is greater than or at least the same amount of debt. But for shareholders or management, this ratio must be large (Fajaria and Isnalita, 2018).

Company Growth is the change (decrease or increase) in total assets owned by the company. Asset growth is calculated as the percentage change in current assets against the previous year. The growth ratio is a ratio that describes a company's ability to maintain its economic position amidst economic growth and its business sector (Kasmir, 2019:107).

Fahmi (2014:83) states that the growth ratio is a ratio that measures how much a company's ability to maintain its position in the industry and economic development in general. Company growth shows the extent to which the company's ability to grow and develop one of the company's assets growth. If the company management can utilize the company's assets optimally, it will increase the company's profit. The more efficient the use of company assets, the lower the costs required to finance the operation of the assets. The more effective the use of company assets, the lower the possibility of unused assets. Unused assets can be sold so that the company gets additional funds. According to Jogiyanto (2013:391) company growth is measured using total asset growth (TAG) which compares the difference between total assets of the current year and total assets of the previous year against total assets of the previous year.

Kasmir (2019:198) says the profitability ratio is a ratio to assess a company's ability to generate profits. This ratio also provides a measure of the level of effectiveness of the company's management as indicated by the profit from sales and investment income, which also shows the efficiency of the company.

Husnan and Pudjiastuti (2015:76) say that profitability is intended to measure how a company generates profit from sales, and the assets it owns or from the equity it owns. Kasmir (2019: 198) says in practice company management is required to meet the targets set. To measure the level of profit of a company, the profitability ratio is used. The profitability ratio is a ratio to assess the company's ability to generate profits. This ratio also provides a measure of the level of effectiveness of the company's management as indicated by the profit from sales and investment income, which also shows the efficiency of the company.

According to Kasmir (2019:206) return on equity is the ratio of net income to measure a tax with its capital. The higher this ratio, the better. This means that the position of the owner of the company is getting stronger, and vice versa. ROE can be obtained by comparing net income to the company's total equity.

\subsection{Conceptual Framework of Research}

Based on the theoretical and empirical studies that have been raised, then the research model is as follow:

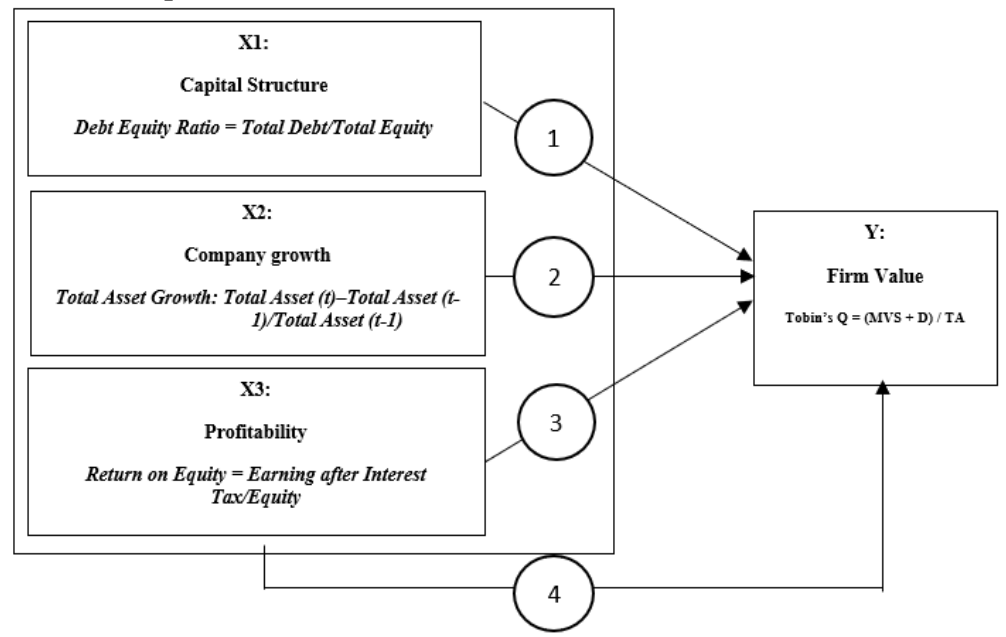

Figure 1. Research Conceptual Framework

Note:

1. The effect of capital structure on firm value.

Previous research conducted by Suzulia et al (2020), Hardinis (2019), Dhani and Utama (2017), and Aggarwal and Padhan (2017) show that capital structure has a positive and significant effect on firm value. However, Meythi and Debbianita (2012) found that firm structure does not affect value. Following the signal theory, companies that have definite equity and debt show that management for operational activities is good. This is a positive signal for investors because they are confident in the hope that they will also get maximum income. The right capital structure and used optimally can provide positive value for company value. 
2. The influence of company growth on firm value.

Previous research conducted by Dhani and Utama (2017) and Fajaria and Isnalita (2018) showed that company growth affects firm value. Meythi and Debbianita (2012) found that company growth does not affect firm value. Following the theory of signal, high asset growth indicates that the chances of the company benefit too high in the future. It is therefore expected with a great growth company will be a consideration for investors to invest, so Firm Value will increase.

3. Effect of profitability on firm value.

Previous research conducted by Dhani and Utama (2017), Fajaria and Isnalita (2018), and Sabrin et al. (2016) showed that profitability affected firm value. Hardinis (2019) and Aggarwal and Padhan (2017) found that profitability does not affect firm value. The higher profitability of the bigger companies. Following the theory of signal that companies with high profitability companies are good at managing resources to generate income to be received in the form of dividends. The investors will be interested in their shares of the company, so the stock price increases. This will increase Firm Value.

4. The effect of capital structure, firm growth, and profitability on firm value.

Previous research conducted by Dhani and Utama (2017) shows that capital structure, company growth, and profitability affect firm value.

\subsection{Research Hipotesis:}

Based on previous research and based on the theory and research conceptual framework, the research hypothesis is as follows:

H1: Capital structure, firm growth, and profitability affect firm value in coal mining sub-sector companies listed on the Indonesia Stock Exchange.

H2: Profitability has the most dominant influence on firm value in coal mining sub-sector companies listed on the Indonesia Stock Exchange.

\section{Research Method}

\subsection{Research Design}

This study uses an explanatory descriptive approach to determine the effect of capital structure, company growth, and profitability on firm value in coal mining sub-sector companies listed on the Indonesian stock exchange through hypothesis testing. The data is obtained from go-public companies listed on the Indonesia Stock Exchange which provide financial reports in a row for the 2015-2019 period. The sampling technique in this study was using a purposive sampling technique.

\subsection{Population and Sample Research}

A study population is several 28 companies listed in Indonesia Stock Exchange in the period 2015-2019. The data of this study were obtained by downloading the financial statements of coal mining sub-sector companies that have been listed on the Indonesia Stock Exchange during 2015-2019. This research sample uses a purposive sampling method so that the selected sample is a representation of the population by the research objectives. The sample selection stage is carried out based on criteria, presented in Table 1.

Based on the results of the sample selection process seen in Table 1. the company obtained as a research sample in 2015-2019 was 12 companies, so the number of observations in the study during 2015-2019 was 60 observations.

Table 1. Sample Selection Stage

\begin{tabular}{|c|l|c|}
\hline No. & \multicolumn{1}{|c|}{ Criteria } & Total \\
\hline 1 & Coal mining companies listed on the Indonesia Stock Exchange. & 28 \\
\hline 2 & Coal mining sector companies that have Initial Public Offering after 2015. & $(2)$ \\
\hline 2 & Coal mining sector companies that had Initial Public Offering before 2015. & 26 \\
\hline 3 & $\begin{array}{l}\text { Coal mining companies that were delisted, suspended by the Indonesia Stock Exchange } \\
\text { and changed their industrial sectors during 2015-2019. }\end{array}$ & $(14)$ \\
\hline 4 & The sample companies. & 12 \\
\hline \multicolumn{2}{|c|}{ Total observes } & 60 \\
\hline
\end{tabular}

\subsection{Data Source and Data Collection}

The data source utilized in this research is secondary data. The secondary data is obtained through a financial statement or publication report on Indonesia Stock Exchange (www.IDX.co.id)

This study, using secondary data, which is in the form of annual financial reports of coal mining subsector companies listed on the Indonesia Stock Exchange 2015-2019. The existing data is obtained from the official website of the Indonesia Stock Exchange.

Methods of data collection in this study is documentation, namely data collection techniques performed by 
studying the financial records on a sample of companies from the Indonesia Stock Exchange, then processed and analyzed using ratio analysis.

\subsection{Data Analysis Technique}

The data analysis method in this study is multiple linear regression. Multiple linear regression analysis is used to test the effect of two or more independent variables on the dependent variable. The dependent variable in this study is a company value, while the independent variable is capital structure, company growth, and profitability. The equations for testing the overall hypothesis in this study are as follows:

$\mathrm{Y}=\alpha+\beta 1 \mathrm{X} 1+\beta 2 \mathrm{X} 2+\beta 3 \mathrm{X} 3+\mathrm{e}$

Information:

Y: Company Value

$\alpha$ : Constant

$\beta 1$ : The regression coefficient of the capital structure

$\beta 2$ : Regression coefficient of company growth

$\beta 3$ : The regression coefficient of profitability

$\mathrm{X} 1$ : Capital structure

X2: Company Growth

X3: Profitability

e: Error

\section{Research Results}

\subsection{Descriptive Analysis}

\begin{tabular}{|l|l|r|r|r|r|}
\hline & $\mathrm{N}$ & \multicolumn{1}{|c|}{ Minimum } & \multicolumn{1}{c|}{ Maximum } & \multicolumn{1}{c|}{ Mean } & \multicolumn{1}{c|}{ Std. Deviation } \\
\hline Debt to Equity Ratio & 60 & .17 & 4.45 & .8515 & .69621 \\
\hline Total Asset Growth & 60 & -.19 & .44 & .0868 & .14032 \\
\hline Return on Equity & 60 & -.48 & .77 & .1755 & .18825 \\
\hline Tobin's Q & 60 & .06 & 3.93 & .9777 & .75667 \\
\hline
\end{tabular}

The lowest value of DER (X1) is 0.17 for the Resources Alam Indonesia company in 2016 and the highest value is 4.45 for the Bayan Resources company in 2015, the average value is 0.8515 with a standard deviation of 0.69621 . The lowest TAG value (X2) was -0.19 for the Bayan Resources company in 2015 and the highest value was 0.44 for the Toba Bara Sejahtera company in 2018. The average value was 0.0868 with a standard deviation of 0.14032 . The lowest value of ROE (X3) is -0.48 for the Bayan Resources company in 2015 and the highest value is 3.93 for the Bayan Resources company in 2018. The average ROE value is 0.1755 with a standard deviation of 0.18825 . The lowest score for Tobin's Q (Y) was 0.06 for the Indonesian Natural Resource company in 2015 and the highest value was 3.93 for the Bayan Resources company in 2018. Tobin's Q average value was 0.9777 with a standard deviation of 0.75667 .

\subsection{Classical assumption test results}

\subsubsection{Heteroscedasticity Test}

Previous observation data were 60 observations, with outlier data as many as 9 observations, namely n8, n11, n12, $\mathrm{n} 13, \mathrm{n} 14, \mathrm{n} 15, \mathrm{n} 49, \mathrm{n} 54$, and n59. The number of observations after deducting outlier data became 51 observations. After the outlier data is removed, the Glesjer test is performed.

The results of the Glesjer test are the significant value of the debt equity ratio (X1) of 0.356 , greater than 0.05 and it can be said that there are no symptoms of heteroscedasticity. The significant value of total asset growth (X2) of 0.850 is greater than 0.05 and it can be said that there are no symptoms of heteroscedasticity. The significant value of return on equity (X3) of 0.227 is greater than 0.05 and it can be said that there is no symptom of heteroscedasticity.

\subsubsection{Normality test}

The results of the normality test of this research variable can be said that the data is normally distributed if all the variables have a significant value greater than $0.05(\mathrm{p}<0.05)$. From the results of the analysis, the unstandardized residual value is 0.096 and the research variable has an Asymp value. Sig. (2-tailed) of 0.200, where 0.200>0.05, it can be said that the data is normally distributed.

\subsubsection{Multicollinearity Test}

Based on the multicollinearity test results, the tolerance value of DER is 0.723 , greater than 0.1 , and the VIF value on the DER variable of 1.383 is less than 10, it can be said that there is no multicollinearity. The tolerance value of the TAG is 0.770 , which is greater than 0.1 and the VIF value of the TAG variable of 1.298 is less than 10 , so it can be said that there is no multicollinearity. The tolerance value of ROE of 0.679 is greater than 0.1 and the VIF value of the ROE variable is 1.473 , which is smaller than 10 , so it can be said that there is no multicollinearity. 
Based on the analysis results in the explanation above, it can be concluded that there is no multicollinearity in the data.

\subsubsection{Autocorrelation Test}

The run test results obtained the Asymp value. Sig. (2-tailed) is 0.890 , where the value is $0.890>0.05$, it is concluded that the residual is random or there is no autocorrelation between the residual values.

\subsection{Model Analysis and Hypothesis Testing}

Based on the analysis results obtained a significant probability value of 0.000 . The resulting significance value is less than $0.05(\mathrm{p}<0.05)$, so these results indicate that the variables of capital structure (Debt Equity Ratio), company growth (Total Asset Growth), and profitability (Return on Equity) simultaneously affect the value of the company.

Based on hypothesis testing, capital structure, company growth, and profitability affect firm value. Thus, these results are by Dhani and Utama (2017) in their research that results show that capital structure, company growth, and profitability simultaneously affect firm value.

Tabel 3. Test Result for Multiple Linear Regression Analysis

\begin{tabular}{|c|c|c|c|c|c|}
\hline \multirow[t]{2}{*}{ Model } & \multicolumn{2}{|c|}{ Unstandardized Coefficients } & \multirow{2}{*}{$\begin{array}{c}\begin{array}{c}\text { Standardized } \\
\text { Coefficients }\end{array} \\
\text { Beta }\end{array}$} & \multirow[t]{2}{*}{$\mathrm{t}$} & \multirow[t]{2}{*}{ Sig. } \\
\hline & B & Std. Error & & & \\
\hline Capital structure & 019 & .148 & .018 & .128 & .899 \\
\hline Company growth & 247 & .401 & .085 & .615 & .541 \\
\hline Profitability & 1.573 & .432 & .534 & 3.639 & .001 \\
\hline
\end{tabular}

Based on table 3, the results of the regression analysis show that the capital structure variable has a significant value of 0.899 , this value is greater than $\alpha=5 \%$ or 0.05 , so it can be said to be insignificant. Company growth has a significant value of 0.541 , this value is greater than $\alpha=5 \%$ or 0.05 , so it can be said to be insignificant. Profitability has a significant value of 0.01 , this value is smaller than $\alpha=5 \%$ or 0.05 , so it can be said to be significant.

\subsection{Determination Coefficient Analysis}

The results of the analysis obtained an Adjusted R2 value of 0.270 or $27 \%$. The $27 \%$ value indicates that the percentage of influence of the independent variable on capital structure (Debt to Equity Ratio), company growth (Total Asset Growth), and profitability (Return on Equity) on the dependent variable of firm value is $27 \%$. So, it can be concluded that the independent variables used in this study can only explain $27 \%$ of the variation in the dependent variable, while the remaining $73 \%$ are explained or influenced by other variables not included in this study.

\section{Research Result Discussion}

\subsection{The Effect of Capital Structure, Company Growth, and Profitability on Firm Value}

Firm value is the price a prospective buyer is willing to pay if the company is sold. The higher the value of the company, the more prosperous the owner of the company is. Factors considered capable of influencing firm value include a capital structure with a debt equity ratio indicator, company growth using a total asset growth indicator, and profitability as measured by an indicator of return on equity. The simultaneous test results (f test) show that capital structure, firm growth, and profitability simultaneously influence firm value. This means that coal mining sub-sector companies listed on the Indonesia Stock Exchange need to increase debt and asset growth and increase profitability, which in turn will increase company value. This research is in line with research conducted by Dhani and Utama (2017). In his research, he found that the capital structure, company growth, and profitability simultaneously influence firm value.

\subsection{The Effect of Capital Structure on Firm Value}

The results of this study indicate that the capital structure does not affect firm value. The high or low level of debt owed by the company does not affect the value of the company, which means that in the coal mining sector on the Indonesia Stock Exchange, it can be concluded that the movement of the share price of a coal mining company is more caused by other factors. Investors do not pay attention to the size of the debt owed by the company, and investors pay more attention to how the company's managers use funds from debt effectively and efficiently to achieve company goals. This research is in line with research conducted by Pratiwi et al. (2016) and Meythi and Debbianita (2012). In his research, he found that the capital structure does not affect firm value.

\subsection{The Effect of Company Growth on Firm Value}

The results of this study indicate that company growth has no effect on firm value. Companies that experience an increase in assets will also be followed by an increase in operating results which will also illustrate the level of 
profit earned by the company but this causes the profits earned by the company to be used for expansion which will ultimately cause investors or owners not to get dividends. Investors usually assume that companies that have good prospects are companies that are experiencing growth, but investors do not see this as a positive signal that will affect the level of return on investment. Investors prefer that the company's managers use the funds from profit effectively and efficiently to achieve company goals or to be distributed as dividends rather than expanding. This is in line with research conducted by Meythi and Debbianita (2012). In his research, he found that firm growth did not affect firm value.

\subsection{The Effect of Profitability on Firm Value}

The results of this study indicate that company profitability has a significant effect on firm value. If the company gets a high level of profit, it will attract investors to invest in the company. This is a positive signal received by investors that a company that gets a high level of profit means that the company has good prospects in the future and will affect the rate of return on its investment. The more investors who are attracted to the company, the more the company's stock price will increase, which reflects the company's high value. In this study it can be concluded that profitability is considered by investors in determining the value of a company, investors expect company managers to improve company performance to obtain a high level of profitability. This is in line with research conducted by Dhani and Utama (2017), Fajaria and Isnalita (2018), Sabrin et al. (2016). In his research, he found that company growth has a significant positive effect on firm value.

\subsection{Profitability has the most dominant influence on firm value}

Profitability as measured by return on equity is the only variable that is significant to firm value. This means that firm value is more influenced by profitability. The coefficient of the profitability variable is positive, meaning that the higher the company's income, the more the firm's value will be. These results indicate that the profitability variable does not have a dominant effect on firm value because only one variable in this study is significant.

\section{Conclusion and Suggestion \\ 6.1 Conclusion}

Capital structure, firm growth, and profitability affect firm value. This means that together the level of debt, asset growth, and high company income can be a positive signal for investors and potential investors to invest. This will make the company value higher.

Profitability has a positive effect on firm value. This means that a company that has a high level of profitability indicates that the company's management manages the company's resources so that it can achieve high revenue. This will make the company value higher.

The capital structure does not affect firm value. This means that companies that have a high level of debt have a high level of risk of default. This means that investors pay attention to making decisions to invest in the company.

Company growth does not affect firm value. Management of a growing company requires large funds for its operations. Company funds are more focused on supporting the company's growth than on the welfare of its shareholders. This is because investors have more confidence in established companies than in developing companies. Therefore, although the company's growth is high, it does not have a significant effect on firm value.

Profitability is not a dominant variable to firm value, meaning that the level of company income is an important factor but not the main reason that investors or potential investors invest in the company.

\subsection{Suggestion}

Based on the results of this study, the author's suggestions for interested parties are as follows:

1) Investors and potential investors in the coal mining sub-sector listed on the Indonesia Stock Exchange should pay more attention to the profitability ratio as a consideration in making investments.

2) For future researchers, given the limitations of this study, the authors suggest further researchers increase the number of manufacturing companies that will be used as samples or increase the number of years of observation. Future researchers can also add other factors that have not been used in this study or can use different ratios from this study.

\section{Reference}

[1] Andri, Veno. (2015). Pengaruh Good Corporate Governance Terhadap Kinerja Perusahaan Pada Perusahaan Manufaktur Go Public (Studi Empiris pada Perusahaan yang Terdaftar di BEI 2011 Sampai 2013). BENEFIT Jurnal Manajemen dan Bisnis Volume 19, Nomor 1, hlm 95-112.

[2] Aggarwal, Divya, \& Purna Chandra Padhan. (2017). Impact of Capital Structure on Firm Value: Evidence from Indian Hospitality Industry. Scientific Research Publishing: Theoretical Economics, 7, 982-1000.

[3] Brigham, F., dan J. Houston. (2019). Manajemen Keuangan, Edisi Empat Belas. Buku 2. Salemba Empat, Jakarta.

[4] Chung, K.H and Pruitt, S.W. (1994). A Simple Approximation of Tobin's q, Financial Management, Vol. 23, 
No. 3 Autumn.

[5] Dhani, Isabella, Permata \& A. A. Gde, Satia, Utama. (2017). Pengaruh Pertumbuhan Perusahaan, Struktur Modal, dan Profitabilitas terhadap Nilai Perusahaan. Jurnal Riset Akuntansi dan Bisnis, Universitas Airlangga, 135-148.

[6] Fajaria, Ardina, Zahrah, \& Isnalita. (2018). The Effect of Profitability, Liquidity, Leverage, and Firm Growth of Firm Value with its Dividend Policy as a Moderating Variable. ARC Jurnal: International Journal of Managerial Studies and Research (IJMSR), Volume 6, hlm. 55-69.

[7] Fahmi, Irham. (2014). Manajemen Keuangan Perusahaan dan Pasar Modal. Edisi 4. Jakarta: Media Wacana Mitra Penerbit.

[8] Ghozali, Imam. (2019). Aplikasi Analisis Multivariete Dengan Program IBM SPSS 25. Edisi 9. Cetakan ke IX, Semarang: Badan Penerbit Universitas Diponegoro.

[9] Husnan, S., \& E. Pudjiastuti, 2015, Dasar-dasar Manajemen Keuangan, Edisi Ketujuah, UUP AMP YKPN, Yogyakarta.

[10] Jogiyanto, H. M. (2013) Teori Portofolio dan Analisis Investasi. Edisi Ke-8, BPFE. Yogyakarta.

[11] Kasmir. (2019). Analisis Laporan Keuangan, Jakarta: PT Raja Grafindo Persada.

[12] Kusumajaya, Dewa, Kadek Oka. (2011). Pengaruh Struktur Modal dan Pertumbuhan Perusahaan terhadap Profitabilitas dan Nilai Perusahaan pada Perusahaan Manufaktur Di Bursa Efek Indonesia. Thesis. Universitas Udayana, Denpasar.

[13] M, Hardinis. 2019, Capital Structure and Firm Size on Firm Value Moderated by Profitability. International Journal of Economics and Business Administration. Volume VII, Issue 1, pp. 174-191.

[14] Meythi, Riki, Martusa, \& Debbianita. (2012). Pengaruh Struktur Modal terhadap Nilai Perusahaan dengan Pertumbuhan Perusahaan Sebagai Variabel Moderating. Jurnal Akuntansi Universitas Kristen Maranatha Bandung, 3, 819-843.

[15] Prasetyo, Aries, Heru. (2011). Valuasi Perusahaan. PPM: Jakarta Pusat.

[16] Pratiwi, Ni Putu Yuni, Fridayana Yudiaatmaja, \& I Wayan Suwendra. (2016). Pengaruh Struktur Modal dan Ukuran Perusahaan Terhadap Nilai Perusahaan. E-Journal Bisma, Universitas Pendidikan Ganesha, 4, 1-8.

[17] Sabrin, Buyung, Satria, Dedy Takdir S, \& Sujono. (2016). The Effect of Profitability on Firm Value in Manufacturing Company at Indonesia Stock Exchange. The Ijes: The International Journal Of Engineering And Science, 5, 81-89.

[18] Salvatore, Dominick. (2011). Ekonomi Manajerial, Buku 1, Salemba Empat, Jakarta.

[19] Suzulia, Maya, Topani, Sudjono, \& Ahmad, Baadawi, Saluy. (2020). The Effect Of Capital Structure, Company Growth, and Inflation on Firm Value With a Profitability As Intervening Variable (Study On Manufacturing Companies Listed On BEI Period 2014-2018). Dinasti International Journal Of Economics, Finances \& Accounting. Universitas Mercubuana Jakarta. Vol.1, Issue 1, Halaman 95-109. 